\title{
更生相談所とリハビリテーション
}

\author{
小池 純子*
}

\section{Counseling Center for the Rehabilitation of People with Physical Disabilities : Programs and the Role of Physiatrists}

\begin{abstract}
Junko KoIKE*
Abstract: The Counseling Centers for the Rehabilitation of People with Physical Disabilities are administrative agencies established in each prefecture as required by the Law for the Welfare of People with Physical Disabilities. With the enactment of this law in 1949, the Counseling Centers were designated as centers for specialized technology to perform a pivotal role in the implementation of welfare policy for the disabled. The Counseling Centers provide counseling, evaluation, and guidance, and conduct inquiries into the kinds of services required by disabled persons, in conjunction with the welfare services delivered by local governments. Specifically, the Centers evaluate an individual's need for medical rehabilitation services, introduce the use of rehabilitation facilities, and counsel on issues related to prosthetic, orthotic, and other technical aids. Counseling and support are also provided to individuals returning to work and community life. The Centers assist prefectural governments by offering specialized medical and technical expertise to aid in the official certification of physically disabled individuals and by promoting rehabilitation programs in the community. For villages, towns, and municipal governments, the Centers coordinate the delivery of welfare services, assist in collecting and disseminating technical and specialized information for educational purposes, and conduct training for staff of local government agencies. Physiatrists play an important role in each Center's counseling and evaluation programs by providing medical evaluations that serve as the basis for an individual's social and occupational rehabilitation objectives. When fitting prosthetic and orthotic devices, for example, because of the precision fit required to compensate for functional disability, the physiatrist is intimately involved in the entire process, from prescription of the device to final evaluation of the individual's adaptation to it. Social conditions have changed dramatically in the fifty plus years since the enactment of the Law for the Welfare of Physically Disabled Persons. Over this time the needs of disabled persons have also greatly increased and diversified in nature. In response to these changing conditions, the year 2003 will mark the beginning of a new welfare system. Accordingly, the services offered by the Counseling Centers for the Rehabilitation of People with Physical Disabilities will also be reviewed. The overall reform of the general medical system is also moving forward. The task confronting the field of rehabilitation medicine is one of developing a new system, and rethinking each aspect, from evaluating the occurrence of disabilities to implementing medical rehabilitation services and restructuring the lives of the disabled in the community.
\end{abstract}


Key words : 身体障害者更生相談所 (Counseling Center for the Rehabilitation of People with Physical Disabilities), 身体障害者福祉法（the Law for the Welfare of People with Physical Disabilities), 専門的技術的中枢機関 (center for specialized technology), 相談判定業務 (counseling and evaluation programs)

\section{はじめに}

身体障害者更生相談所および知的障害者更生相 談所は，それぞれ身体障害者福祉法（第 11 条）， 知的障害者福祉法（第 12 条）の規定により都道 府県が設置する行政機関である.

更生相談所は法の制定以来, 福祉行政推進の専 門的技術的中枢機関として位置付けられてきた. しかし, 生活水準の向上, 少子・高齢化の進行な ど社会情勢の変化に伴って, 福祉行政全体が新た な局面を迎えている現在, 更生相談所において も, 時代の要請に応じた役割の見直し, 体制整備 が緊急の課題である.

一方，介護保険の導入や医療制度改革のもと， 障害者のリハビリテーション（以下，リハ）を取 り巻く状況の変化も著しい. 障害の発生から障害 者の地域での生活の再構築に至るまでに必要な保 健・医療・福祉サービスをどのように開発・発展 させていくのか, 我々リ八医療に携わる医師（以 下，リ八医）の課題でもある.

本稿では身体障害者更生相談所の役割について 述べる。

\section{身体障害者更生相談所をめぐる動向}

身体障害者更生相談所（以下，更生相談所） は，1949 年 12 月身体障害者福祉法（以下，身障 法）の制定により設置が規定され，身体障害者 （以下，障害者）の更生に関する中枢的機関とさ れた.

以降, 福祉行政の変遷のなか, 更生相談所に求 められる役割も, 施設入所等の判定機能から地域 リ八の中核機能，市町村等に対する専門的技術的 援助機能へと変化してきた。

1994 年「社会保障将来像委員会第 2 次報告」
が公表され, その後の介護保険や社会福祉基礎構 造改革の骨格が示された.

2000 年 4 月「地方分権の推進を図るための関 係法律の整備等に関する法律 (地方分権一括法)」 が施行された. 更生相談所については, その名 称の弾力的運用が可能となり, 新たな業務に, (1) 市町村福祉担当職員の教育, 指導, 研修支 援，（2) 基準外補装具交付に係る厚生大臣協議廃 止に伴う, 基準外補装具の專門的判定, (3) 補装 具装着訓練の市町村指導等, が加わった.

同年 6 月には「社会福祉の増進のための社会福 祉事業法等の一部を改正する等の法律」が成立し た。同法に扔いて障害者福祉サービスは, 利用者 の立場に立った制度を構築するため, 2003 年 4 月より新たな利用の仕組みである利用契約制度 （支援費制度）に移行することとなった。

更生相談所は，これまで以上に專門的，技術的 機能を発揮するよう求められる一方, その現状に ついては, 地域格差の拡大や専門的業務の実施体 制整備の遅れも指摘されている. 飯田ら ${ }^{1)}$ は, 2000 年度の厚生科学特別研究において全国更生 相談所実態調査を実施, その結果を踏まえ厚生労 働省に「身体障害者更生相談所のあり方検討委員 会」が設けられた。

\section{更生相談所の設置運営基準と現状 ${ }^{1,2)}$}

\section{1. 設置}

設置主体は都道府県および指定都市である。

設置形態は他の関連する相談所や福祉施設, 医 療施設などとの総合的運営を図るため, これらの 相談所や施設と併設することも差し支えなく, 更 生相談所が地域リ八推進の中核となるため, いわ ゆる総合リハセンターとして一体化することが望 ましいとされてきた。

現在全国に 68 カ所の更生相談所が設置されて 
いるが, 設置形態は「単独設置」が数力所に留ま り，残りは，組織が一本化され施設長が 1 人の 「総合施設として設置」されているもの, 同一敷 地内または同一建物内に他施設があるが組織とし ては独立した「併設型」のものが，それぞれおよ そ半数ずつである。

表1 更生相談所の標準的職員配置(単独設置の場合)3)

\section{所長}

医師

嘱託医師（専任医師以外の整形外科，外科，内科，眼 科, 耳鼻咽喉科)

身体障害者福祉司

心理判定員

職能判定員

ケース・ワーカー

保健士または看護師

\section{事務職員}

設置を予定する職種：理学療法士, 作業療法士, 義肢 装具士

配置が望まれる職種：職能訓練士，言語聴覚士，視能 訓練士
また, 更生相談所と医療機能（病院，診療所 等）の有無について飯田らは，更生相談所の業務 を遂行する上で医療機能は密接な関係にあり，医 療機能を持つ更生相談所（全国 7 カ所）は持たな いものに比べて業務の実施状況が極めて高いとい う調査結果を示している.

\section{2. 職員配置}

更生相談所には，所長および事務職員のほか, 市町村間の連絡調整，各種判定，相談などの専門 的機能を維持するために専門的職員を配置するこ ととなっている．表 1 に専門的職員の標準的な配 置を示した。

飯田らは，更生相談所業務の実施状況につい て，法改正に伴う新たな役割のみならず，従来か らの業務の実施に関しても地域格差が著しいが, その原因は，職員体制の不備にあるとしている。 即ち, 職員定数の設定数が少なく人材の確保や充 足が困難なため兼任や非常勤が多く，特に必須の

表 2 更生相談所の業務3)

\begin{tabular}{|c|c|}
\hline \multirow[t]{9}{*}{ 判定・診査 } & 医学的 - 心理学的 - 職能的判定 \\
\hline & 補装具判定 \\
\hline & 更生医療判定 \\
\hline & 更生援護施設入所判定 $\longrightarrow 2003$ 年度より支援費制度へ移行 \\
\hline & 巡回による相談判定 \\
\hline & 訪問診査 \\
\hline & 審査委員会 \\
\hline & $\begin{array}{l}\text { 人工透析審査委員会 } \\
\text { 障害程度審査委員会 } \\
\text { 基準外補装具審査会 }\end{array}$ \\
\hline & 進行性筋萎縮症者療養等の給付の要否意見書 \\
\hline 専門的相談・指導 & 技術的援助・指導 \\
\hline & $\begin{array}{l}\text { 市町村への専門的支援 } \\
\text { 更生援護施設への専門的支援 } \\
\text { 市町村職員の研修 } \\
\text { 専門情報の収集・提供 }\end{array}$ \\
\hline 連絡調整 & 更生援護施設入所の連絡調整 \\
\hline 地域リハビリテーション推進 & 地域リハビリテーション推進事業 \\
\hline & $\begin{array}{l}\text { 地域リハビリテーション協議会 } \\
\text { リハビリテーション関係職員研修 } \\
\text { リハビリテーション関係調查研究 }\end{array}$ \\
\hline
\end{tabular}


医療, 福祉専門職が確保されていない実状が窥え ると述べている。

\section{更生相談所の運営, 業務の概要}

市町村が，社会福祉の第一線の実施機関である のに対し, 更生相談所は, 相談・判定等の専門技 術的サービスを担当する機関である，その具体的 業務内容は，設置運営基準に示されている．表 2 に業務の内容を分類し示した.このうち，リハ医 療に関連の深い業務について解説する。

\section{1. 判定業務}

更生相談所の判定は市町村が障害者の更生援護 を実施する際に求められるものであり，判定業務 には医学的判定, 心理学的判定, 職能的判定業務 がある。

判定の方法として来所判定, 文書判定, 各市町 村への巡回判定, 在宅重度身体障害者訪問診査が 実施される。

また，判定後，当該ケースの更生援護のゴール とプランの決定は判定会議にて合議のもとに行わ れる.判定会議は議長を所長とし，判定を行った 各職員, 市町村の担当者が参加するものである.

なお，更生援護施設（表 3）への入所判定につ いては，2003 年度より支援費制度となるため, 項を改めて述べる。

\section{1) 医学的判定}

障害の重度・重複化，難病などを原因とする障 害の多様化など障害をとりまく現況において，医 学的判定は更生援護の方針を決定する上での基礎 となるものである。医学的判定に係る医師は，関

表 3 身体障害者更生援護施設 (身体障害者福祉法第 5 条)

身体障害者更生施設 身体障害者療護施設 身体障害者福祉ホーム 身体障害者授産施設 身体障害者福祉センター 補装具製作施設 盲導犬訓練施設 視聴覚障害者情報提供施設
係法令上の知識や各種通知に示されているガイド ラインを熟知するとともに，判定を行うことは， 一般の疾病に対する診断治療行為とは異なること を理解し，社会福祉に携わる専門職としての視 点, 即ち, 機能障害を生活モデルという枠組みで 捉える姿勢をもって臨まなければならない。

医学的判定において求められるものは下記のと おりである。

・原疾患および障害の診断, 評価

- 医学的, 社会的, 職業的リ八の要否, 立案

・更生医療の要否と予後予測

・補装具の処方と適合判定

-医学的見地加らの（社会的, 職業的）生活の ゴール

・住宅改造，職場環境整備についての意見

\section{2）更生医療判定*1}

更生医療は身障法施行規則第 4 条別表第 5 号 （身体障害者手帳に該当するもの）に示されてい る障害に対して, 機能の改善, 維持を目的として 行われるものである。近年の医療制度の充実によ り，本制度はすでに形骸化しており，公費負担医 療制度の一形態として存在するに過ぎない.

更生医療の医学的判定については医療給付の適 否，医療を実施する部位，具体的治療方針，軽減 される障害の程度などを示すこととされている。

\section{3) 補装具判定 ${ }^{3)}$}

\section{(i ) 補装具とは}

補装具とは身障法および児童福祉法に規定され た法律上の用語であり，法的に給付保障すること が決められたものの総称である．補装具の種目範 囲は身障法では第 20 条によって規定されている. 同時に，補装具はリ八医療において，身体の欠

${ }^{* 1}$ 育成医療（児童福祉法第 20 条) ${ }^{9)}$ ：育成医療は，身体 に障害のある児童（身体障害者手帳の所持とは直接関 係はない。）を対象とし，早期治療による身体障害の 予防ないし防止を主眼としている. 育成医療の給付は 都道府県が厚生労働大臣又は都道府県知事が指定する 医療機関（指定育成医療機関）に委託して行う。育成 医療が更生医療と異なる点は，後者が，現にある機能 障害を除去又は軽減するのに対し, 前者は, 放置すれ ば将来著しい障害をもたらす恐れのある障害又は障害 の原因となる疾病の治療を含むことである。なお，児 童とは満 18 歳に満たない者をいう。 
損や機能障害による能力低下を補完, 代償する重 要な手段の 1 つである. 福祉用具給付制度等検討 委員会の報告においても (1999 年 2 月), 補装具 とは，(1)身体の欠損または損なわれた身体機能 を補完・代償するもの，（2 身体に装着（装用） して常用するものまたは作業に使用するもの, ( 3 ) 給付に際して医師の意見書（更生相談所に来 所の場合は判定書）を必要とするもの，以上 3 つ の条件を満たすものとしており，その処方や適合 判定に医師が介在することの重要性を明らかにし ている.

(ii ) 補装具判定の流れ

市町村長は, 障害者から補装具の交付・修理の 申請を受けた場合，この交付の要否について更生 相談所の医学的判定を求めなければならない.ま た，判定に基づいて製作または修理された補装具 を給付する時には，更生相談所の適合判定を受け なければならない。図 1 に補装具の申請から給付 までの流れを示した。

更生相談所による医学的判定は, 障害の具体的 状況，補装具の交付または修理に関する意見（必 要とする理由, 根拠), 必要とする補装具の名称 または修理項目, 処方内容として型式, 主材料, 工作法または基本構造, 付属品等, 補装具を使用
した場合の効果見込み等についての判定を行う. なお，処方内容はそれによって製作を開始できる 程度の詳しいものでなければならない（処方箋の 利用).

義肢, 装具, 座位保持装置の型取り，仮合わせ については，更生相談所の指導のもとに実施する とされている。

適合判定は更生相談所の行う技術検査である. 処方箋に基づき，身体との適合性，物理的構造， 材質，外観性についてチェックする，不適合が認 められた場合は，補装具製作業者に対し不備な個 所を指摘し改善させる，また，更生相談所はこれ らの業務を適正に実施するため，製作業者に対す る指導を行うものである.

\section{(iii）判定の方法とリハ医の役割 4 )}

補装具は，その種目によって事務的な取り扱い 方法や更生相談所による判定の必要性および判定 の方法が異なり，補装具の種目および価格は「補 装具の種目，受託報酬の額等に関する基準 」5) に， 取り扱いについては「補装具給付事務取扱要領」, 「補装具給付事務取扱いに関する指針」として厚 生労働省から通知されている。最近改正された指 針では，更生相談所で交付の判定をすべき補装具 の種目が具体的に挙げられ，種目によっては医師

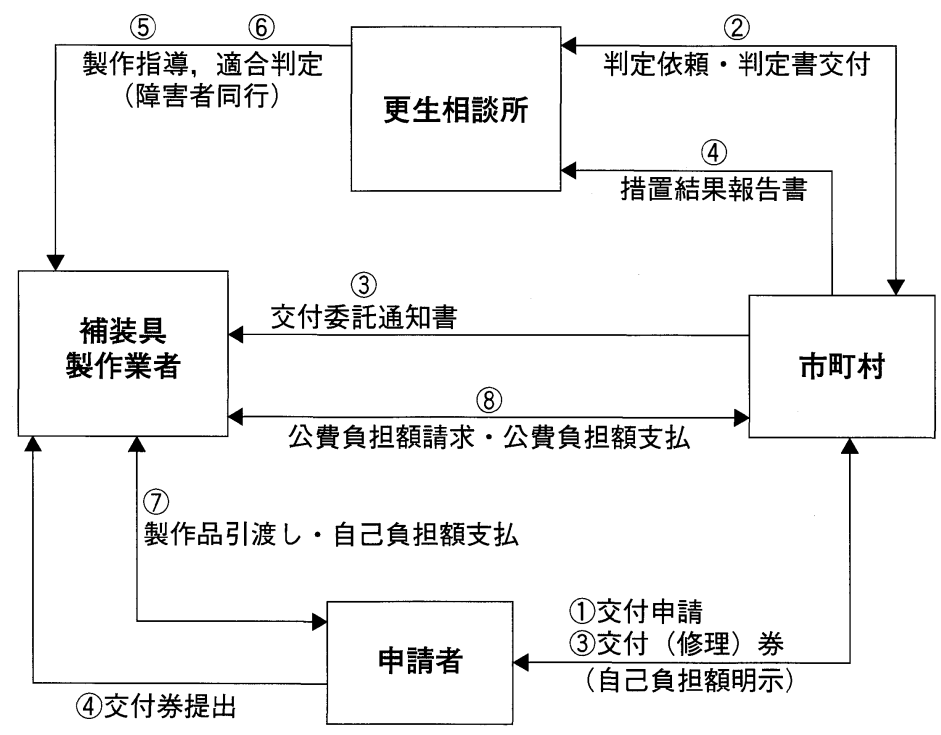

図 1 補装具給付事務の流れ 
表 4 補装具新規交付に係る判定事務

\begin{tabular}{|c|c|c|c|}
\hline \multicolumn{2}{|c|}{ 更生相談所の医学的判定を要するもの } & \multicolumn{2}{|c|}{ 更生相談所の医学的判定を要しないもの } \\
\hline 障害者の来所により判定 & 医師の意見書により判定 & 市町村が判断（要医師の意見書） & 市町村が判断 \\
\hline $\begin{array}{l}\text { 義肢, 装具, 座位保持装置 } \\
\text { 車いす（オーダーメイド） } \\
\text { 電動車いす }\end{array}$ & $\begin{array}{l}\text { 弱視眼鏡，補聴器 } \\
\text { 車いす（レディメイド） } \\
\text { 頭部保護帽（オーダーメイド） }\end{array}$ & $\begin{array}{l}\text { 矯正眼鏡，コンタクトレンズ } \\
\text { 義眼，人工喉頭（笛式） } \\
\text { 手押し型車いす（レディメイド） } \\
\text { 遮光眼鏡 } \\
\text { 歩行器 }\end{array}$ & $\begin{array}{l}\text { 盲人安全つえ, 色めがね, 点字器 } \\
\text { 人工啹頭 (電動式), 収尿器 } \\
\text { ストマ用装具, 歩行補助つえ } \\
\text { 頭部保護帽 (レディメイド) }\end{array}$ \\
\hline
\end{tabular}

の意見書などによる判定を認めるなど，文書判定 を拡大する方向性が示されている（表 4).

文書判定における意見書を作成できる医師の要 件について，厚生労働省の指針は，「更生相談所 長が選定した専門医（身障法第 15 条の指定医ま たは第 19 条の指定医療機関の中から関係医学会 等の意見に基づいて選定), 公的機関が実施する 補装具判定医師研修を修了した者など十分な専門 知識, 技能, 経験を有する者」としている。

日本整形外科学会と日本リ八医学会は義肢装具 に係る医師のガイドライン゙)を作成し（1988 年), 処方, 採寸・採型, 適合チェックを医師の 役割と明記したが，公的給付制度によって補装具 を交付する場合，意見書を作成したり，更生相談 所から委嘱され医学判定を行うことも医師の役割 である。

一方, 補装具給付後に市町村が行う装着訓練お よび実施観察において，更生相談所は専門的な見 地から市町村を支援すること, 市町村が身体障害 児に補装具を交付する際*2, 必要に応じ更生相談 所に技術的助言を求めるものとされており, 更生 相談所は障害児・者の補装具利用に関しては一貫 して専門的役割を果たすことが要請されている.

*2 児童への補装具交付 (児童福祉法第 21 条)：地方分権 一括法により，身体障害児に係る補装具の給付事務が 都道府県から市町村に委譲された。対象は身体障害者 手帳の交付を受けた児童であり，補装具の給付を希望 する児童は原則として療育指導等実施保健所または指 定育成医療機関の担当医師の意見書を添えて市町村に 申請する。市町村は補装具を交付する際, 必要に応じ 更生相談所に技術的助言を求めるものとされている. なお，基準外補装具の交付については，療育指導等実 施保健所または指定育成医療機関の判定に基づいて市 町村が決定するが, 療育指導等実施保健所または指定 育成医療機関は必要に応じ更生相談所に技術的助言を 求めるものとされている.
リハ医においては，積極的に係るべき業務と認識 し，補装具に関する知識や技術水準の向上に努め ることが望まれる。

\section{（iv）補装具の基準外交付の判定}

基準外の補装具とは, 障害者の現症, 生活環境 その他やむを得ない事情により，告示に定められ た補装具の種目に該当するもので，別表に定める 名称，型式，基本構造等によることができない補 装具をいう。

地方分権一括法の施行により基準外補装具交付 に係る厚生大臣協議が廃止されたため, 基準外補 装具を交付する必要が生じた場合，専門的判定を 更生相談所が行うこととなった。これらの判定を 実施するにあたり，基準外補装具審査会の設置な ど判定体制の整備が求められているが，基準によ らない特殊な補装具であることから，医学判定に おいても高い専門性が必要と考える.

\section{（v）介護保険制度の施行（2000 年）に伴う補 装具の適用関係}

身障法における補装具のうち車いす, 歩行器, 歩行補助つえは, 介護保険の福祉用具貸与対象品 目となった。このため，介護保険の要介護者また は要支援者で身体障害者手帳を所持している者に ついても，標準的な既製品で対応できる場合は介 護保険で貸与を受けることになる，ただし，更生 相談所の判定により障害者の身体状況等にあわせ て個別に製作することが必要と判断された場合は 補装具として給付される。また，介護支援専門員 の福祉用具に関する知識が十分とは言えない現状 では，更生相談所は専門的相談機関の役割も果た すべきであろう。 


\section{2. 地域リ八推進に関する業務}

障害者の更生援護を効果的かつ体系的に実施す る上で，住み慣れた地域で適切なリハサービスが 総合的に提供されることが重要であることから， 地域関係機関相互の連携の推進を図るための事業 を行う（地域リ八推進協議会の設置・運営）.

\section{3. 身体障害者手帳に関連する業務および障害 程度審査委員会設置事業}

身体障害者手帳の取得は身障法によるサービス を受ける前提となるものである。

地方分権一括法の施行により身体障害の認定は 自治事務として位置付けられた。国はガイドライ ンとして身体障害認定基準を示しているが（2003 年 4 月 1 日より新認定基準)，障害認定において 地域格差が生じる恐れが指摘されている。その対 策の 1 つとして身体障害者手帳の申請に必要な診 断書を作成する医師（身障法 15 条指定医師）へ の研修の実施があり，各自治体においては更生相 談所の業務として検討されている。なお，日本り 八医学会障害保健福祉委員会では，リ八医への情 報提供として「身体障害者手帳の書き方に関する 報告書」を示す予定である。

一方，都道府県知事および指定都市（中核市） 市長が身体障害者手帳を交付するにあたっては， 15 条指定医師の作成した診断書に基づいて, 法
別表への該当，非該当，障害等級の程度および再 認定の要否などを決定しなければならない。しか し，医療技術の進歩による治療の可能性や障害像 の複雑化，多様化により，障害の認定を的確に行 うためには専門的知識，経験が必要である。この ようなとき, 都道府県知事は更生相談所長の意見 を聴くものとされているが，障害程度審査委員会 は障害の認定について更生相談所の専門的機能を 活用し，身体障害手帳交付の適正な実施を図るた めに設置されるものである，審査委員会は更生相 談所長, 各障害別の担当医師（更生相談所の医 師，嘱託医師）をもって構成される。

\section{支援費制度と更生相談所の役割 ${ }^{7,8)}$}

2003 年度より措置制度（行政処分）による福 祉サービスの提供システムが市町村による支援費 の支給制度に移行する，改定のポイントは，障害 者が事業者との対等な関係に基づき，障害者自ら がサービス選択し，事業者と直接契約を結び，サ ービスを利用することである.リハ医との関係で は，本制度では，これまで更生援護施設を利用す る場合に必須とされていた更生相談所の入所判定 が不要となり，それに伴う医学的判定の役割がな くなることである．更生施設などの利用にあたっ て, 更生相談所の判定が省略されることは, 夕イ

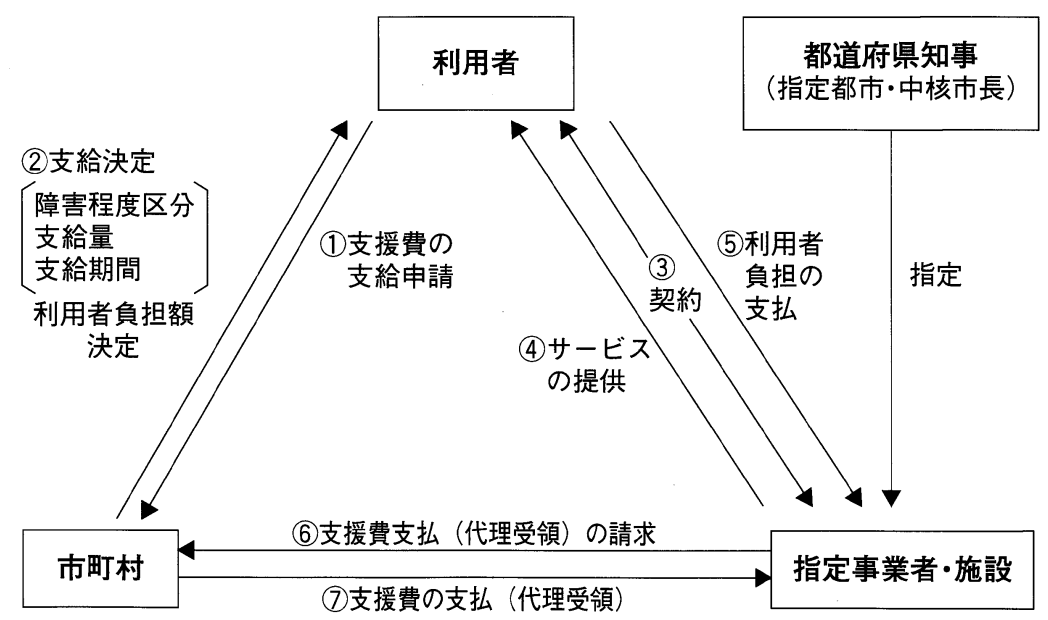

図 2 支援費制度の基本的な仕組み 
表 5 支援費制度の対象となるサービス

\begin{tabular}{|c|c|c|c|}
\hline & 身体障害者福祉法 & 知的障害者福祉法 & 児童福祉法（障害児関係のみ） \\
\hline 施設訓練等支援 & $\begin{array}{l}\text { 身体障害者更生施設 } \\
\text { ・身体障害者療護施設 } \\
\text { ・身体障害者授産施設 } \\
\text { (小規模通所授産施設を除く) }\end{array}$ & $\begin{array}{l}\text { - 知的障害者更生施設 } \\
\text { ・知的障害者授産施設 } \\
\text { (小規模通所授産施設を除く） } \\
\text { ・知的障害者通勤寮 } \\
\text { ・心身障害者福祉協会が設置する } \\
\text { 福祉施設 }\end{array}$ & \\
\hline 居宅生活支援 & $\begin{aligned} \text { ・身体障害者居宅介護等事業 } \\
\text { (ホームヘルプサービス) } \\
\text { ・身体障害者デイサービス事業 } \\
\text { ・身体障害者短期入所事業 } \\
\text { (ショートステイ) }\end{aligned}$ & $\begin{array}{l}\text { ・知的障害者居宅介護等事業 } \\
\text { (ホームヘルプサービス) } \\
\text { ・知的障害者デイサービス事業 } \\
\text { ・知的障害者短期入所事業 } \\
\text { (ショートステイ) } \\
\text { ・知的障害者地域生活援助事業 } \\
\text { (グループホーム) }\end{array}$ & $\begin{array}{l}\text { - 児童居宅介護等事業 } \\
\text { (ホームヘルプサービス) } \\
\text { ・児童デイサービス事業 } \\
\text { ・児童短期入所事業 } \\
\text { (ショートステイ) }\end{array}$ \\
\hline
\end{tabular}

ムリーな施設利用という点でも大きな改善である.

\section{1. 基本的な仕組み}

支援費制度では障害程度区分の決定を市町村が 行い，決定に基づいて支援費が支給される．本制 度の基本的な仕組みは図 2 に示したとおりであ る.

まず，障害者福祉サービス（表 5）の利用につ いて支援費支給を希望する者（身体障害者手帳の 所持が前提）は，必要に応じて適切なサービス選 択のための相談支援を受け，市町村に支援費支給 の申請を行う.

申請を受理した市町村は，支給を行うことが適 切であると認めるときは，支援費の支給決定を行 なう，即ち，居宅生活支援費であれば，支給量と 期間を，施設訓練等支援費であれば，障害程度区 分と支給期間を決定する。障害程度区分（3段 階）の決定は, 各施設支援ごとの聴き取り表によ り行う。この区分に基づいて，これまでの措置費 に代わり支援費（施設訓練等支援費）が支給され ることになる。

支給決定を受けた者は，都道府県知事の指定を 受けた指定業者・施設との契約により，障害者福 祉サービスを利用する。

\section{2. 更生相談所の役割}

1）相談支援体制の充実

市町村は障害者に対する情報提供, 相談・指導
について支援費の支給申請の受付等に関連づけな がら責任をもって取り組むこととされており，ま た, 市町村の相談業務とあわせ, 市町村障害者生 活支援事業を行う相談支援事業者, 更生相談所, 児童相談所, 福祉事務所等の多様な主体が相談業 務の担い手となることが期待されている．特に， 更生相談所は, 市町村, 事業者と連携を図り, 専 門的な知識や技術を活用して，障害者等が障害者 福祉サービスを主体的かつ適切に選択できるよう に相談支援することとされている。

\section{2）サービス利用に係るあっせん・調整，要請}

障害者の希望により行う, サービス利用に係る あっせん・調整, 要請は市町村の業務であるが, これについては市町村相互間の連絡調整等を行う ことが必要であり, 更生相談所が都道府県の機関 として連絡調整の役割を担うことが考えられてい る.

また，支援費制度下では，利用者がサービスを 選択するのが基本であるが，利用希望者が多数の 場合など施設サービスの利用が円滑かつ公平に行 われるよう, 公的メカニズム（入所調整会議）が 機能することが重要であり, 更生相談所の役割と して考えられている.

\section{3）障害程度区分に係る判定}

先に述べたように，支援費制度では支援費（施 設訓練等支援費）支給に先立って，障害程度区分 の決定を市町村が行う。身障法施行規則におい て,「市町村は, 居宅支給決定, 支給量の変更も 
しくは決定の取り消し，施設支給決定，障害程度 区分の変更もしくは支給決定の取り消しを行うに 当たって，特に医学的・心理的および職能的判定 を必要とする場合には，更生相談所の判定を求め るものとする」とされており，意見を求められた 更生相談所は，医学的・心理学的および職能的判 定を行い，市町村は，更生相談所の判定を勘案し て障害程度区分の決定等を行う。

更生相談所は, 市町村からの要請によって判定 を必要とする場合には意見を述べる立場にある が，障害程度区分の決定はあくまでも市町村が責 任をもって行うものである。

\section{4）研修などにおける指導}

支援費制度においては，障害状況が同程度であ る障害者に係る障害程度区分の結果が, 決定を行 う市町村により著しく異なることがないよう，更 生相談所は研修等を通じて市町村に対して指導を 行うことが期待される。

\section{更生相談所のあり方}

地方分権一括法の施行, 支援費制度の導入に伴 い，障害者福祉行政は新たな局面を迎えている。 また，障害者をとりまく状況も変化してきてい る。このような変化と時代の要請に応えるため, 「身体障害者更生相談所のあり方検討委員会」が 設置された。「検討委員会」では, 更生相談所の 基本的な位置付け，業務の明確化，市町村支援の あり方, 研修体制のあり方を検討課題とし, 身体 障害者更生援護の専門的・技術的中枢である更生 相談所が地域リハの中核を担うべきと結論付けて いる。また，更生相談所がその役割を果たすため に望まれる, 組織体制, 設置形態, 職員体制等の 実施体制を都道府県の実情別に提言している．特 に, 設置形態については, 更生相談所業務におけ る医学的判定の重要性や市町村が対応困難な医学 的問題 (高次脳機能障害, 遷延性意識障害, 重複 障害等）への指導の必要性を指摘し更生相談所の 医療機能の持ち方について具体的に示している. すなわち, 更生相談所長は臨床経験 15 年以上の 肢体不自由を専門とする医師が望ましいこと, 事
務職が所長の場合, 臨床経験が 6 年以上の肢体不 自由を専門とする常勤医師を配置すること，医療 機能をもたない単独または併設型の更生相談所は リ八医療機能の充実した大学・公的総合病院，リ 八専門病院等の医療機関と密接な連携を図ること （具体的には専門医・職の派遣等）である.

今後,「検討委員会」の報告書に基づき, 更生 相談所設置要綱の見直しや更生相談所業務マニュ アルがまとめられる予定である。

\section{おわりに}

身体障害者更生相談所の役割をリ八医療に携わ る医師との関連および法改正に伴う役割の変化な どを中心に解説した。

現在，医療保険制度，介護保険制度，社会福祉 制度など，時代の要請によって様々な制度改革が 進められているが，今後の見直しも含めいまだ流 動的な状態である，身体障害および知的障害者福 祉の領域では，「高次脳機能障害支援モデル事業」 や「自閉症・発達障害支援センター運営事業」な どが開始されるなど，多様化する障害への取り組 みも行われている。将来的には，精神障害も含め 3 障害を統合した社会福祉制度への移行，また， 相互扶助に基づく保険制度と国家責任で行われる 社会福祉制度との関係もさらに整理されていくも のと予想される。

リハ医として業務を行う上で関連の深いこれら の分野の重要性を認識し，また，リ八医の専門性 を発揮できる分野の 1 つとして積極的な関わりを 望みたい。

\section{文献}

1）飯田 勝（主任研究者）：法改正に伴う身体障害者更 生相談所のあり方に関する研究. 厚生科学研究費補助 金 厚生科学特別研究事業, 平成 12 年度

2）障害者保健福祉制度研究会 監修：身体障害者福祉関 係法令通知集 (13 年度版). 第一法規, 東京, 2002

3）厚生省社会援護局更生課監修：身体障害者更生相談所 事務マニュアル. 中央法規出版, 東京, 1995

4) 永田雅章, 伊藤利之, 岩谷 力, 山口 明, 樫本 修, 佐 伯 覚, 佐々木鐵人, 住居広士, 中島咲哉, 原 行弘: 身体障害者福祉法による補装具交付の判定に関する調 查. リ八医学 $2002 ; 39$ : 604-607 
5）日本義肢協会 編：補装具の種目，受託報酬の額等に 関する基準. 付) 完成用部品等の指定基準. 身体障害者 福祉法 厚生労働省告示 第 121 号 (平成 14 年 3 月 27 日改正)

6）日本整形外科学会，日本リハビリテーション医学会 編：義肢装具にかかわる医師のガイドライン. 義肢装 具のチェックポイント (第 5 版). 医学書院, 東京, 1998 ; p 308
7）厚生労働省援護局障害保健福祉部：全国身体障害者更 生相談所及び知的障害者更生相談所所長会議資料, 平 成 14 年 8 月

8）厚生労働省社会援護局障害保健福祉部：支援費制度担 当課長会議資料（支援費制度事務処理要領）. 平成 14 年 6 月

9）児童福祉法規研究会 編：児童福祉法の解説. 時事通 信社, 東京, 2000 